\title{
Maternal Thyroid Function is the Major Determinant of Amniotic Fluid 3,3',5'-Triiodothyronine in the Rat
}

\author{
Mohamed M. El-Zaheri, Apostolos G. Vagenakis, Lee Hinerfeld, \\ Charles H. Emerson, and Lewis E. Braverman, Division of Endocrinology \\ and Metabolism, University of Massachusetts Medical School, \\ Worcester, Massachusetts 01605
}

A в S T R A C T $3,3^{\prime}, 5^{\prime}$-triiodothyronine, $\left(\mathrm{rT}_{3}\right)$, is easily measured in human amniotic fluid (AF) during the second and third trimesters. To determine if $\mathrm{AF} \mathrm{rT}_{3}$ levels are maintained by either maternal or fetal thyroid function, or both, models of fetal hypothyroidism (FH), maternal hypothyroidism ( $\mathrm{MH}$ ), and combined maternal and fetal hypothyroidism (MFH) were developed in pregnant rats. Hormone analyses of maternal and fetal serum and AF were performed at term. Thyroxine $\left(\mathrm{T}_{4}\right)$ and $3,3^{\prime}, 5$-triiodothyronine $\left(\mathrm{T}_{3}\right)$ were not detectable in the sera and AF of term fetuses in all groups. MFH rats were prepared by administration of methimazole to the dams, and in some experiments, by maternal thyroidectomy and a low iodine diet as well. In the MFH groups from the three experiments serum thyrotropin (TSH) was markedly elevated in the dams and in the fetuses. FH rats were prepared by administering $T_{4}$ by various routes to dams treated according to the MFH protocols and serum TSH was elevated in fetal serum. Analysis of FH maternal serum $\mathrm{T}_{4}, \mathrm{~T}_{3}$, and $\mathrm{TSH}$ concentrations suggested mild maternal hyperthyroidism or hypothyroidism depending upon the schedule of $\mathrm{T}_{4}$ administration. The MH groups were prepared by maternal thyroidectomy and in all experiments the fetuses had normal serum TSH concentrations. The degree of maternal hypothyroidism in the MH and MFH groups was equivalent. The mean concentration of $\mathrm{AF}_{\mathrm{rT}}$ in normal rats in three experiments was $28.4 \pm 2.5 \mathrm{ng} / \mathrm{dl}$

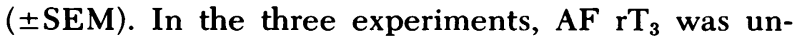
detectable or markedly reduced in the $\mathrm{MH}$ and $\mathrm{MFH}$ rats and was normal in the $\mathrm{FH}$ rats. These results in

This work was presented, in part, at the 62nd Annual Meeting of the Endocrine Society, 18-20 June 1980, Washington, D. C.

Dr. El-Zaheri's present address is Medical University of Jordan, Amman, Jordan. The present address of Dr. Vagenakis is University of Patras Medical School, Patras, Greece.

Received for publication 28 August 1980 and in revised form 17 November 1980. the amniotic fluid could not be explained by transfer of $\mathrm{rT}_{3}$ from fetal serum to the $\mathrm{AF}$ because fetal serum $\mathrm{rT}_{3}$ concentrations in these various models did not correlate with $\mathrm{AF} \mathrm{rT}_{3}$ concentration. Furthermore, infusion of large doses of $\mathrm{rT}_{3}$ in $\mathrm{MFH}$ dams resulted in a 35-fold elevation in maternal serum $\mathrm{rT}_{3}$ concentration, a twofold elevation in fetal serum $\mathrm{rT}_{3}$ concentration, and only a minimal increase in $\mathrm{AF} \mathrm{rT}_{3}$. These studies demonstrated that, in the rat, the maternal thyroid has the dominant role in maintaining $\mathrm{AF} \mathrm{rT}_{3}$, whereas little effect of fetal thyroid status on $\mathrm{AF} \mathrm{rT}_{3}$ could be demonstrated. Transfer of maternal $\mathrm{rT}_{3}$ or of fetal $\mathrm{rT}_{3}$ derived from maternal $\mathrm{T}_{4}$ to the AF do not appear to be the mechanisms whereby the maternal thyroid maintains $\mathrm{AF} \mathrm{rT}_{3}$.

\section{INTRODUCTION}

Patients with congenital hypothyroidism have profound retardation of physical, mental, and motor development (1). A number of workers have sought a means to diagnose congenital hypothyroidism antenatally. In 1975 Chopra and Crandell (2) observed that amniotic fluid (AF) 3,3',5'-triiodothyronine (reverse $\left.\mathrm{T}_{3}, \mathrm{rT}_{3}\right)^{1}$ concentrations were easily detectable during human pregnancy, in contrast to low or undetectable concentrations of thyroxine $\left(T_{4}\right)$ and $3,3^{\prime}, 5^{\prime}$-triiodothyronine $\left(T_{3}\right)$. These observations have been confirmed by others (3-6) and aroused considerable interest, suggesting that $\mathrm{AF} \mathrm{rT}_{3}$ measurements might be a useful means of diagnosing fatal hypothyroidism in utero $(7,8)$.

\footnotetext{
${ }^{1}$ Abbreviations used in this paper: AF, amniotic fluid; BW, body weight; C group, control group; FH group, fetal hypothyroidism group; LID, low-iodine diet; MFH group, combined maternal-fetal hypothyroidism group; $\mathrm{MH}$ group, maternal hypothyroidism group; MMI, methimazole; $\mathrm{rT}_{3}$, reverse $\mathrm{T}_{3} ; \mathrm{T}_{3}, 3,3$, 5 -triiodothyronine; $\mathrm{T}_{4}$, thyroxine; $\mathrm{TSH}$, thyrotropin; Tx, thyroidectomized.
} 
Since AF $\mathrm{rT}_{3}$ could be dependent upon either maternal or fetal thyroid function or both, studies were carried out in experimental rat models of fetal hypothyroidism, maternal hypothyroidism, and combined maternal-fetal hypothyroidism. The ovine species was not chosen for these studies since term $\mathrm{AF} \mathrm{rT}_{3}$ concentrations are low in the sheep (8). Previously published rat (9-17) and primate $(18,19)$ models of fetal hypothyroidism were not used since hypothyroidism had been induced at birth rather than in the fetus or combined maternal-fetal hypothyroidism resulted from the treatment regimen. When an effort was made to prepare isolated fetal hypothyroidism, pharmacologic doses of $\mathrm{T}_{4}$ were administered to dams receiving antithyroid drugs and/or a low-iodine diet (LID) (20). Moreover, at the time many of these studies were performed, it was not possible to characterize the hormonal status of mother and fetus by specific and sensitive measurements of $\mathrm{T}_{4}, \mathrm{~T}_{3}$, and thyrotropin (TSH) concentrations.

In this report several treatment regimens for inducing isolated maternal or fetal hypothyroidism in the rat are described. The hormonal status of these models have been characterized and they have been used to derive information on the source of the relatively large concentration of $\mathrm{rT}_{3}$ in $\mathrm{AF}$. The data demonstrate that reduced $\mathrm{AF} \mathrm{rT}_{3}$ in these models are indicative of maternal, rather than fetal, hypothyroidism.

\section{METHODS}

Virgin Sprague-Dawley 10-wk old female rats (Charles River Breeding Laboratories, Wilmington, Mass.) were used in these studies. They were cycled and mated in our laboratory (experiment 1) or received from the supplier during the lst wk of pregnancy (experiments 2 and 3). Methimazole (MMI, tapazole) was a gift from Eli Lilly \& Co. (Indianapolis, Ind.). LID was purchased from Teklad Test Diets (Madison, Wis.) and Alzet osmotic minipumps were obtained from Alza Corp. (Palo Alto, Calif.). Stable $\mathrm{rT}_{3}$ was purchased from Washington Reference Laboratory (Washington, D. C.) and $\mathrm{L}-\mathrm{T}_{4}$ from the Sigma Chemical Co. (St. Louis, Mo.).

Treatment protocols. Pregnant rats were housed in separate cages with free access to Purina Lab Chow and water in a temperature $\left(21 \pm 1^{\circ} \mathrm{C}\right)$-and light $(700-800)$-controlled room. Specific treatment, including TX, was begun on day 8 in experiment 1 , day 7 in experiment 2 , and day 11 in experiment 3. Table I shows the protocols for inducing combined maternal-fetal hypothyroidism (MFH group), fetal hypothyroidism (FH group), or maternal hypothyroidism (MH group). In each experiment, untreated pregnant rats served as the control group (C group). All animals received $1 \%$ calcium lactate in the drinking water since hypocalcemia was common in the thyroidectomized $(\mathrm{Tx})$ rats.

In experiment 1 , the MFH group was prepared by the addition of $0.05 \% \mathrm{MMI}$ to the drinking water. In experiment 2 , the MFH group, in addition to receiving MMI in the drinking water, underwent maternal $\mathrm{Tx}$ under light ether anesthesia and received a LID. The protocol for the $\mathrm{MFH}$ group in experiment 3 was identical to experiment 2 except
TABLE I

Protocols Used for Inducing Maternal and/or Fetal Hypothyroidism

\begin{tabular}{|c|c|c|c|}
\hline \multirow[b]{2}{*}{ Group } & \multicolumn{3}{|c|}{ Maternal treatment } \\
\hline & $\begin{array}{c}\text { Exp. } 1 \\
(8)\end{array}$ & $\begin{array}{c}\text { Exp. } 2 \\
\text { (7) }\end{array}$ & $\begin{array}{c}\text { Exp. } 3 \\
\text { (11) }\end{array}$ \\
\hline MFH & MMI* & $\begin{array}{l}\text { MMI } \\
\text { TX } \\
\text { LID }\end{array}$ & $\begin{array}{l}\text { MMI } \\
\text { TX }\end{array}$ \\
\hline $\mathrm{FH}$ & $\begin{array}{l}\mathrm{MMI} \\
\mathrm{T}_{4}\end{array}$ & $\begin{array}{l}\text { MMI } \\
T_{x} \\
L_{I D} \\
T_{4}\end{array}$ & $\begin{array}{l}\text { MMI } \\
T x \\
T_{4}\end{array}$ \\
\hline MH & $\mathrm{Tx}$ & $\mathrm{Tx}$ & $\mathrm{T} x$ \\
\hline C & None & None & None \\
\hline
\end{tabular}

$\mathrm{T}_{4}$ was administered in experiment 1 from day 8 to day 20 as a single s.c. injection of $1.5 \mu \mathrm{g} / 100 \mathrm{~g} \mathrm{BW}$; in experiment 2 via s.c. osmotic pump from day 7 to day 21 in a daily dose of $1.2 \mu \mathrm{g} /$ $100 \mathrm{~g} \mathrm{BW}$; in experiment 3 from day 11 to day 20 in s.c. doses of $0.75 \mu \mathrm{g} / 100 \mathrm{~g} \mathrm{BW}$ BID. Number in parentheses indicates the day maternal treatment was begun.

$* 0.05 \% \mathrm{MMI}$ in drinking water.

that the LID was not used. In experiment 3 an additional group of MFH rats were studied. These rats received a subcutaneous infusion via osmotic minipump of $10 \mu \mathrm{g}$ $\mathrm{rT}_{3} / 100 \mathrm{~g}$ body wt (BW) during the last $5 \mathrm{~d}$ of pregnancy. In each experiment, the $\mathrm{FH}$ group received identical treatment as the MFH group except that physiologic doses of $\mathrm{T}_{4}$ were administered to the dams. In experiment 1 , the $\mathrm{FH}$ dams were killed $24 \mathrm{~h}$ after the last daily $\mathrm{T}_{4}$ injection; in experiment 2 they were killed at the time $\mathrm{T}_{4}$ was being infused via osmotic minipump; and in experiment 3 they were sacrificed $12 \mathrm{~h}$ after the last b.i.d. (twice daily) injection of $\mathrm{T}_{4}$. In all experiments the $\mathrm{MH}$ groups were prepared by maternal $\mathrm{Tx}$.

Sample collection. On the 21 st d of pregnancy, the dams were killed by decapitation and trunk blood was collected. The abdomen was then rapidly opened and AF was obtained by amniocentesis from the amniotic sac of each fetus and combined into one pool for each litter. The fetuses were then quickly delivered by hysterotomy, decapitated, and the trunk blood from each fetus collected and combined into one pool for each litter. Samples were stored at $-20^{\circ} \mathrm{C}$ after centrifugation.

Hormone analyses. Serum and $\mathrm{AF} \mathrm{T}_{4}$ and $\mathrm{T}_{3}$ concentrations were measured by radioimmunoassay (21). $\mathrm{rT}_{3}$ was measured by radioimmunoassay using anti-r $\mathrm{T}_{3}$ antibody supplied by Dr. Sidney Leskowitz (Tufts University, Boston, Mass.) in a final dilution of 1/2,800. ${ }^{125}$ I-labeled $\mathrm{rT}_{3}$ was purchased from New England Nuclear (Boston, Mass.). Labeled $\mathrm{rT}_{3}$ was displaced from anti-rT $\mathrm{T}_{3}$ antibody in a semilogarithmic fashion with the intercept at $50 \%$ displacement being $85 \mathrm{ng} / \mathrm{dl}$. The crossreaction of $3,3^{\prime} \mathrm{T}_{2}, \mathrm{~T}_{3}$, and $\mathrm{T}_{4}$ was $0.5,0.03$, and $0.12 \%$, respectively. In each assay the least detectable concentration of $\mathrm{rT}_{3}$ was considered to be that giving a response $2 \mathrm{SD}$ away from the 0 dose. To correct for serum and amniotic fluid effects on the assay, hormone-free rat serum or amniotic fluid prepared by charcoal extrac- 


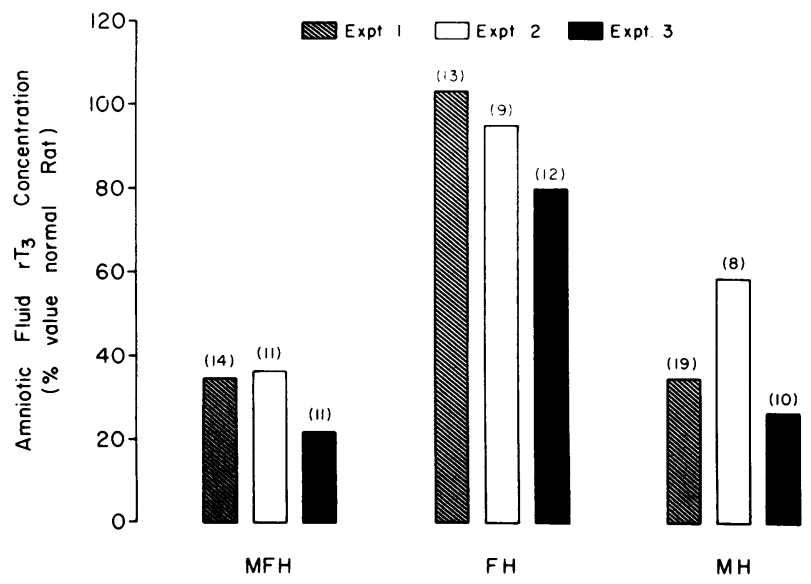

Figure 1 The effect of maternal and fetal thyroid status on amniotic fluid rT3 concentrations. All values for AF $\mathrm{rT}_{3}$ were undetectable in the $\mathrm{MFH}$ and $\mathrm{MH}$ groups in experiment 1 and in the MFH group in experiment 3 . When all values in a group were undetectable, the mean value assigned to the group was the value for the lower limit of detectability of the assay. Numbers in parentheses represent number of AF specimens in each group.

tion were added to the respective standard curves in amounts identical to that used for the unknown samples. Serum and AF TSH was measured by radioimmunoassay using materials kindly supplied by the Hormone Distribution Officer, $\mathrm{Na}$ tional Institute of Arthritis, Metabolism, and Digestive Diseases, National Institutes of Health, Bethesda, Md. All assays were performed in duplicate and all samples from each experiment for each hormone were assayed concurrently. All results are expressed as the mean \pm SEM. In those assays in which some values were detectable and a minority of samples were below the sensitivity of the assay, the undetectable samples were assigned a value at the lower limit of sensitivity.

Statistical analyses. The data was analyzed by Kendall's test with Fisher's corrections for multiple comparisons when comparisons were made between groups in which hormone concentrations were undetectable (22). When hormone concentrations were all detectable, values were analyzed by one way analysis of variance followed by the NewmanKeuls test to detect differences of means (22).

\section{RESULTS}

The results are summarized in Tables II-V and Fig. 1. The three experiments are discussed separately since different regimens were used in each to prepare the $\mathrm{MFH}$ and FH groups.

\section{Experiment 1 (Table II)}

Maternal thyroid status. Maternal hypothyroidism was induced in the appropriate groups since maternal serum TSH was significantly elevated and $T_{4}$ and $T_{3}$ significantly lower in the MFH and $\mathrm{MH}$ rats as compared with the group $\mathrm{C}$ rats. Maternal hypothyroidism was greater in the $\mathrm{MH}$ group than in the MFH group as judged by maternal serum TSH concentrations $(\mathrm{MH}$, $335 \pm 20 \mu \mathrm{U} / \mathrm{ml}$ vs. $\mathrm{MFH}, 243 \pm 14 \mu \mathrm{U} / \mathrm{ml}, P<0.01$ ). There was no evidence of maternal hypothyroidism in the FH group because maternal serum TSH was suppressed and serum $T_{4}$ and $T_{3}$ concentrations were not significantly different from the corresponding values in the $C$ group.

Fetal thyroid status. Fetal hypothyroidism was present in the MFH and FH groups since fetal serum TSH was significantly elevated in these groups as compared to $\mathrm{C}$ group rats. In this and subsequent experiments, $T_{4}$ and $T_{3}$ were not detectable in fetal serum in any group, including the normal $\mathrm{C}$ group. Therefore, fetal serum $T_{4}$ and $T_{3}$ measurements could not be used to characterize fetal thyroid status. In the MH group there was no evidence of fetal hypothyroidism because fetal serum TSH concentrations in the MH and $\mathrm{C}$ groups were similar. The degree of fetal

TABLE II

Maternal Serum, Fetal Serum, and AF Concentrations of $T_{4}, T_{3}, r T_{3}$, and TSH in Experiment 1

\begin{tabular}{lccccr}
\hline & & \multicolumn{4}{c}{ Group } \\
\cline { 3 - 6 } \multicolumn{1}{c}{ Hormone } & Specimen & MFH (14) & FH (13) & MH (19) & C (10) \\
\hline $\mathrm{T}_{4}, \mu g / d l$ & MS & $<0.3^{*}$ & $1.2 \pm 0.1$ & $<0.3^{*}$ & $1.8 \pm 0.3$ \\
$\mathrm{~T}_{3}, n g / d l$ & $\mathrm{MS}$ & $12.6 \pm 1.0$ & $21.6 \pm 2.1$ & $16.8 \pm 1.5^{*}$ & $25.5 \pm 1.8$ \\
$\mathrm{rT}_{3}, n g / d l$ & $\mathrm{MS}$ & $14.3 \pm 2.6$ & $15.4 \pm 2.1$ & $<6.0^{*}$ & $19.5 \pm 5.5$ \\
& $\mathrm{FS}$ & $16.1 \pm 0.9^{*}$ & $24.2 \pm 0.9^{*}$ & $24.4 \pm 0.8^{*}$ & $31.3 \pm 2.3$ \\
& $\mathrm{AF}$ & $<11.5^{*}$ & $34.3 \pm 3.0$ & $<11.5^{*}$ & $33.1 \pm 4.6$ \\
$\mathrm{TSH}, \mu U / m l$ & $\mathrm{MS}$ & $243 \pm 14^{*}$ & $<32$ & $335 \pm 20^{*}$ & $47.1 \pm 6.0$ \\
& $\mathrm{FS}$ & $150 \pm 7^{*}$ & $116 \pm 12^{*}$ & $<32$ & $<32$ \\
\hline
\end{tabular}

MS, maternal serum; FS, fetal serum. Values are mean \pm SE. The following hormones were undetectable in all groups: $\mathrm{FS} \mathrm{T}_{4}<0.3, \mathrm{FS} \mathrm{T}_{3}<0.3, \mathrm{AF} \mathrm{TSH}<34, \mathrm{AF} \mathrm{T}_{3}<10$. Numbers in parentheses represent the number of dams, litters, and AF in each group. ${ }^{*} P<0.01$ vs. $\mathrm{C}$ group. 
hypothyroidism in the $\mathrm{FH}$ group was not as severe as fetal hypothyroidism in the MFH group since fetal serum TSH was significantly lower $(\mathrm{FH}, 116 \pm 12$ $\mu \mathrm{U} / \mathrm{ml}$ vs. $\mathrm{MFH}, 150 \pm 7, P<0.05)$. This may be due to the transplacental passage of small quantities of $\mathrm{T}_{4}$, which would be accentuated by the administration of a single daily bolus of $T_{4}$ resulting in transient supraphysiological concentrations of plasma $T_{4}$ in the dam.

Maternal serum $r T_{3}$. Concentrations of $\mathrm{rT}_{3}$ in maternal serum were similar in all rats except the $\mathrm{MH}$ group in which $\mathrm{rT}_{3}$ was undetectable.

Fetal serum $r T_{3}$. Fetal serum $\mathrm{rT}_{3}$ concentrations were significantly reduced in the $\mathrm{MFH}, \mathrm{FH}$, and $\mathrm{MH}$ rats as compared to the $\mathrm{C}$ group. In MFH rats, fetal serum $\mathrm{rT}_{3}$ was significantly lower than in the $\mathrm{FH}$ or MH groups $(P<0.01)$.

$A F r T_{3} . \quad \mathrm{rT}_{3}$ was undetectable in $\mathrm{AF}$ in the $\mathrm{MFH}$ and $\mathrm{MH}$ groups. In contrast, $\mathrm{AF} \mathrm{rT}_{3}$ was not reduced in the $\mathrm{FH}$ group $(\mathrm{FH}, 34.3 \pm 3.0 \mathrm{ng} / \mathrm{dl}$ vs. $\mathrm{C}, 33.1 \pm 4.6)$.

\section{Experiment 2 (Table III)}

In this experiment, several modifications of experiment 1 were made. In the FH groups, dams underwent Tx and were given a LID as well as MMI in the drinking water. They were replaced with $\mathrm{T}_{4}$ by osmotic minipumps rather than with a single daily injection of $\mathrm{T}_{4}$ to minimize the transplacental passage of $\mathrm{T}_{4}$, which may have occurred in experiment 1 . In addition, Tx and a LID as well as MMI were included in the treatment regimen of the $\mathrm{MFH}$ group since, in experiment 1 where MMI alone was used, maternal hypothyroidism was not as great in the $\mathrm{MFH}$ as in the MH group.

Maternal thyroid status. As in experiment 1 , analy- sis of maternal serum $\mathrm{T}_{4}, \mathrm{~T}_{3}$, and $\mathrm{TSH}$ documented the presence of maternal hypothyroidism in the $\mathrm{MFH}$ and $\mathrm{MH}$ groups. In contrast to experiment 1 , maternal serum TSH concentrations in these groups did not differ significantly. Maternal hypothyroidism was present in the FH group since the serum $\mathrm{T}_{3}$ concentration was significantly lower and the serum TSH concentration significantly elevated in the $\mathrm{FH}$ as compared to the $\mathrm{C}$ group. However, maternal serum $\mathrm{T}_{4}$ concentrations in the $\mathrm{FH}$ and $\mathrm{C}$ groups were not significantly different from each other.

Fetal thyroid status. The treatment regimen induced a similar degree of fetal hypothyroidism in the $\mathrm{MFH}$ and $\mathrm{FH}$ groups in that fetal serum TSH concentrations were equally elevated. As in experiment 1 , there was no evidence of fetal hypothyroidism in the MH group in that the fetal serum TSH concentration in this group was normal.

Maternal serum $\quad r T_{3} . \quad \mathrm{rT}_{3}$ concentrations ranged from undetectable to $41.5 \mathrm{ng} / \mathrm{dl}$ in the $\mathrm{C}$ group and were undetectable in the other three groups.

Fetal serum $r T_{3}$. As noted in experiment 1 , the fetal serum $\mathrm{rT}_{3}$ concentration in the $\mathrm{MH}$ rats was intermediate between values observed in the $\mathrm{C}$ group and the MFH group and was significantly lower in the MFH as compared to the MH group $(P<0.01)$. However, unlike experiment 1 , the fetal serum $\mathrm{rT}_{3}$ concentration was not decreased in the $\mathrm{FH}$ group.

$A F r T_{3}$. As in experiment $1, \mathrm{AF}_{\mathrm{rT}_{3}}$ was normal in the $\mathrm{FH}$ group and markedly decreased in the $\mathrm{MH}$ and $\mathrm{MFH}$ groups. Unlike experiment 1 , where $\mathrm{AF} \mathrm{rT}_{3}$ was undetectable in these latter two groups, $\mathrm{AF} \mathrm{rT}_{3}$ was detectable and significantly higher in the $\mathrm{MH}$ as compared with the $\mathrm{MFH}$ rats $(\mathrm{MH}, 13.5 \pm 0.8$ vs. $\mathrm{MFH}$, $8.4 \pm 0.9, P<0.05)$.

TABLE III

Maternal Serum, Fetal Serum, and AF Concentrations of $T_{4}, T_{3}, r T_{3}$, and TSH in Experiment 2

\begin{tabular}{lccccr}
\hline & & \multicolumn{4}{c}{ Group } \\
\cline { 3 - 6 } \multicolumn{1}{c}{ Hormone } & Specimen & MFH (11) & FH (9) & MH (8) & C (15) \\
\hline $\mathrm{T}_{4}, \mu g / d l$ & MS & $<0.5^{*}$ & $3.6 \pm 0.2$ & $<0.5^{*}$ & $3.6 \pm 0.3$ \\
$\mathrm{~T}_{3}, n g / d l$ & MS & $6.1 \pm 0.7^{*}$ & $23.5 \pm 3.3^{*}$ & $9.5 \pm 0.9^{*}$ & $52.3 \pm 3.6$ \\
$\mathrm{rT}_{3}, n g / d l$ & MS & $<10^{*}$ & $<10 \ddagger$ & $<10 \ddagger$ & $18.1 \pm 2.9$ \\
& FS & $13.9 \pm 1.1^{*}$ & $30.6 \pm 1.7$ & $21.1 \pm 0.8^{*}$ & $34.8 \pm 1.8$ \\
& AF & $9.2 \pm 0.5^{*}$ & $22.0 \pm 1.4$ & $13.5 \pm 0.8^{*}$ & $23.1 \pm 1.2$ \\
$\mathrm{TSH}, \mu U / m l$ & $\mathrm{MS}$ & $337 \pm 23^{*}$ & $323 \pm 45^{*}$ & $279 \pm 27^{*}$ & $72 \pm 5$ \\
& FS & $186 \pm 17^{*}$ & $187 \pm 8^{*}$ & $88 \pm 16$ & $83 \pm 3$ \\
\hline
\end{tabular}

MS, maternal serum; FS, fetal serum. Values are mean \pm SE. The following hormones were undetectable in all groups: $\mathrm{FS}<0.5, \mathrm{FS} \mathrm{T}_{3}<5.4, \mathrm{AF} \mathrm{T}_{4}<0.4, \mathrm{AF}_{3}<10$, $\mathrm{AF}$ TSH $<40$. Numbers in parentheses represent the number of dams, litters, and AF in each group.

${ }^{*} P<0.01$ vs. $\mathrm{C}$ group.

$\ddagger P<0.02$ vs. C group. 
TABLE IV

Maternal Serum, Fetal Serum, and AF Concentrations of $T_{4}, T_{3}, r T_{3}$, and TSH in Experiment 3

\begin{tabular}{lccccr}
\hline & & \multicolumn{4}{c}{ Group } \\
\cline { 3 - 6 } Hormone & Specimen & MFH (11) & FH (12) & MH (10) & C (9) \\
\hline $\mathrm{T}_{4}, \mu g / d l$ & MS & $<0.4^{*}$ & $1.2 \pm 0.1 \pm$ & $<0.4^{*}$ & $2.3 \pm 0.1$ \\
$\mathrm{~T}_{3}, n g / d l$ & MS & $20.4 \pm 3.2^{*}$ & $48.2 \pm 8.2^{*}$ & $15.2 \pm 1.8^{*}$ & $87.4 \pm 4.2$ \\
$\mathrm{rT}_{3}, n g / d l$ & $\mathrm{MS}$ & $7.2 \pm 2.0$ & $13.7 \pm 3.0$ & $5.9 \pm 2.0$ & $8.7 \pm 1.8$ \\
& $\mathrm{FS}$ & $<3.5^{*}$ & $11.6 \pm 0.8^{*}$ & $18.6 \pm 5.8$ & $19.0 \pm 1.0$ \\
& $\mathrm{AF}$ & $6.4 \pm 1.1^{*}$ & $25.4 \pm 1.8$ & $8.3 \pm 1.5^{*}$ & $31.9 \pm 2.8$ \\
$\mathrm{TSH}, \mu U / m l$ & $\mathrm{MS}$ & $308 \pm 16^{*}$ & $112 \pm 22$ & $343 \pm 20^{*}$ & $<60$ \\
& $\mathrm{FS}$ & $170 \pm 11^{*}$ & $157 \pm 10^{*}$ & $<60$ & $69 \pm 4$ \\
\hline
\end{tabular}

MS, maternal serum; FS, fetal serum. All values are mean \pm SE. The following hormones were undetectable in all groups: $\mathrm{FS} \mathrm{T}_{4}<0.4$, FS $\mathrm{T}_{3}<4.0, \mathrm{AF}_{4}<0.4, \mathrm{AF} \mathrm{T}_{3}<10$, AF TSH $<34$. Numbers in parentheses represent the number of dams, litters, and AF in each group.

$* P<0.01$ vs. C group.

$\ddagger P<0.02$ vs. C group.

\section{Experiment 3 (Table IV)}

In experiment 1 , mild maternal hyperthyroidism was present in the FH group and fetal hypothyroidism was not as marked in this group as compared to the MFH group. Modification of the treatment regimen in experiment 2 corrected these problems but resulted in some maternal hypothyroidism in the FH group as judged by an elevation in maternal serum TSH. In experiment 3 , a third regimen for $\mathrm{T}_{4}$ administration was evaluated in the FH group, namely b.i.d. injections of $\mathrm{T}_{4}$.

Maternal thyroid status. As in experiments 1 and 2, analysis of maternal serum $\mathrm{T}_{4}, \mathrm{~T}_{3}$, and TSH concentrations documented the presence of maternal hypothyroidism in the MFH and MH groups. The degree of maternal hypothyroidism in these two groups was similar since maternal serum $T_{4}, T_{3}$, and TSH concentrations did not differ significantly. Maternal serum $T_{4}$ and $T_{3}$ concentrations were significantly lower in the $\mathrm{FH}$ as compared to the $\mathrm{C}$ group. The elevation in maternal serum TSH in the FH group as compared to the $\mathrm{C}$ group only achieved significance if Fisher's correction for multiple comparisons was not used $(P<0.01)$.

Fetal thyroid status. As noted in experiment 2, fetal serum TSH concentrations were elevated to a similar degree in the $\mathrm{FH}$ and $\mathrm{MFH}$ groups. Fetal serum TSH, as in previous experiments, was normal in the MH group.

Maternal serum $r T_{3}$. Maternal serum $\mathrm{rT}_{3}$ concentrations were frequently undetectable and no difference was observed between the four groups.

Fetal serum $r T_{3}$. Fetal serum $\mathrm{rT}_{3}$ concentrations were significantly lower in the $\mathrm{FH}$ as compared to the $\mathrm{C}$ group. Serum $\mathrm{rT}_{3}$ was undetectable in the $\mathrm{MFH}$ group.

$A F \quad r T_{3} . \quad A F \quad \mathrm{rT}_{3}$ concentrations were low or undetectable in the MFH and MH groups. In contrast, $\mathrm{AF} \mathrm{rT}_{3}$ was similar in the $\mathrm{FH}$ and $\mathrm{C}$ groups. Identical findings were noted in the two previous experiments.

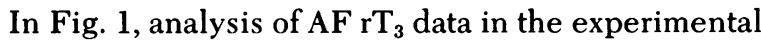
groups is displayed as a percentage of that observed in the control group. It is evident that $\mathrm{AF} \mathrm{rT}_{3}$ is markedly decreased in the presence of maternal hypothyroidism irrespective of fetal thyroid status ( $\mathrm{MH}$ and $\mathrm{MFH}$ ), but is normal when fetal hypothyroidism alone is present.

\section{$r T_{3}$ infusion in $\mathrm{MFH}$ dams}

Table $\mathrm{V}$ shows that the constant infusion of large quantities of $\mathrm{rT}_{3}$ into MFH dams for $5 \mathrm{~d}$ resulted in a marked elevation of maternal serum $\mathrm{rT}_{3}$ concentrations $(315 \pm 26 \mathrm{ng} / \mathrm{dl})$. In spite of the fact that maternal

\section{TABLE V}

Effect of $r T_{3}$ Infusion in MFH Dams on Maternal Serum, Fetal Serum, and $\mathrm{AF} r \mathrm{~T}_{3}$ Concentrations

\begin{tabular}{lrccc}
\hline & & \multicolumn{3}{c}{$\mathrm{rT}_{3}$} \\
\cline { 3 - 5 } \multicolumn{1}{c}{ Group } & $n$ & MS & FS & AF \\
\hline Normal dams & 9 & $9 \pm 2$ & $19 \pm 1$ & $32 \pm 3$ \\
MFH dams & 11 & $7 \pm 2$ & $<3.5$ & $<7.0$ \\
MFH dams $+\mathrm{rT}_{3}{ }^{*}$ & 7 & $315 \pm 26$ & $35 \pm 4$ & $12 \pm 2$ \\
\hline
\end{tabular}

Values are mean $\pm \mathrm{SE}$.

${ }^{*} \mathrm{rT}_{3}$ infused via osmotic minipump in a dose of $10 \mu \mathrm{g} / 100 \mathrm{~g}$ per $\mathrm{d}$ for the last $5 \mathrm{~d}$ of pregnancy. 
serum $\mathrm{rT}_{3}$ concentration was elevated 35 times greater and fetal serum $\mathrm{rT}_{3}$ concentrations were increased approximately twice that observed in normal rats, AF $\mathrm{rT}_{3}$ concentration remained far below that found in normal rats.

\section{DISCUSSION}

Models of maternal hypothyroidism, fetal hypothyroidism, and combined maternal-fetal hypothyroidism have been described in the rat. Combined maternalfetal hypothyroidism in MMI-treated dams (experiment 1 ) was confirmed by the presence of undetectable $\mathrm{T}_{4}$, markedly reduced $\mathrm{T}_{3}$, and elevated TSH concentrations in maternal serum, and an elevated TSH concentration in fetal serum. MMI crosses the placenta and therefore blocks hormone formation in both the maternal and fetal thyroid. In experiment 2 maternal Tx and LID was added to the MMI regimen and in experiment 3 dams were treated with MMI and Tx. It might be expected that the degree of both maternal and fetal hypothyroidism in the MFH groups would have been greatest in experiment 2 because the most severe antithyroid regimen was used in this experiment. However, MFH/C ratios for serum TSH concentration in both maternal and fetal serum were lower in experiment 2 than in experiments 1 or 3 .

Induction of maternal hypothyroidism was consistently achieved by thyroidectomy. In all three experiments, thyroidectomy resulted in undetectable $\mathrm{T}_{4}$, markedly depressed $\mathrm{T}_{3}$, and four- to eightfold elevations of TSH concentration in maternal serum. Moreover, the degree of maternal hypothyroidism achieved was similar to that in the MFH groups since maternal serum TSH concentrations in the MFH group never exceeded that in the $\mathrm{MH}$ group. There was no evidence of fetal hypothyroidism in the $\mathrm{MH}$ rats.

The greatest problems were encountered in preparing a model of isolated fetal hypothyroidism. The FH groups were treated according to the MFH protocols. In addition, $\mathrm{T}_{4}$ was administered to the dams in a quantity similar to that reported by Gray and Galton (23) to be the physiological replacement dose. However, using the three $\mathrm{T}_{4}$ regimens, it was not possible to both restore serum TSH to normal in the dam and leave the elevated serum TSH in the fetus unaffected. In experiment 1 the single daily dose of 1.5 $\mu \mathrm{g} \mathrm{T}_{4} / 100 \mathrm{~g} \mathrm{BW}$ corrected maternal hypothyroidism but also decreased fetal serum $\mathrm{TSH}$, although this latter value was still markedly elevated. In experiment 2 , the constant infusion of $1.2 \mu \mathrm{g} \mathrm{T}_{4} / 100 \mathrm{~g} \mathrm{BW}$, and in experiment 3 , the b.i.d. administration of $0.75 \mu \mathrm{g} \mathrm{T} \mathrm{T}_{4} /$ $100 \mathrm{~g} \mathrm{BW}$, did not alter fetal serum TSH concentration but maternal serum TSH remained elevated. In experiment 2 , despite the fact that maternal serum $\mathrm{T}_{4}$ con- centration was normal in the $\mathrm{T}_{4}$ infused hypothyroid dams, maternal serum TSH concentration was not decreased and serum $\mathrm{T}_{3}$ concentration was only partially restored to normal. These findings in the $T_{4}$ infused rats were not unexpected for two reasons. First, Conners and Hedge (24) have reported that the constant infusion of a daily dose of $T_{3}$ in hypothyroid rats, which normalizes the serum $T_{3}$ concentration does not suppress serum TSH. The dose of infused $\mathrm{T}_{3}$ that does suppress TSH secretion is associated with an elevated serum $T_{3}$ concentration. Because the only source of $\mathrm{rT}_{3}$ is $\mathrm{T}_{4}$, it was important in the present experiment to maintain a normal serum $\mathrm{T}_{4}$ concentration. This was achieved with the dose of $1.2 \mu \mathrm{g} \mathrm{T} \mathrm{T}_{4}$ $100 \mathrm{~g} \mathrm{BW}$. Second, in the rat, thyroid secretion of $\mathrm{T}_{3}$ contributes far more to the serum $\mathrm{T}_{3}$ concentration than in man and the failure to restore serum $T_{3}$ to normal with an infusion of $\mathrm{T}_{4}$ that normalizes the serum $T_{4}$ concentration in the thyroidectomized rat reflects the absence of this thyroid contribution to circulating $\mathrm{T}_{3}$. Finally, the present observations support the findings of Tonooka and Greer (25) that there is a narrow range between the quantity of $T_{4}$ required to induce minimal suppression of serum TSH and that required to suppress TSH secretion to normal in thyroidectomized rats. Since $T_{4}$ and $T_{3}$ were undetectable in normal fetal serum, it was not possible to use these measurements to assess the degree to which fetal hypothyroidism had been induced in the FH groups. The presence of small quantities of $T_{4}$ and $\mathrm{T}_{3}$ remaining in fetal serum in the $\mathrm{FH}$ rats could not be ruled out. However, it is likely that significant depletion of $T_{4}$ and $T_{3}$ occurred since the fetal serum TSH concentration was strikingly elevated.

Various estimates have been made concerning the quantity of maternal $\mathrm{T}_{4}$ that crosses the placenta in the rat. Gray and Galton (23) concluded that both the fetal and maternal thyroid glands contribute to the maintenance of serum $T_{4}$ levels in the fetus but were not able to make a quantitative estimate of the maternal contribution (23). More recently, Dussault and Coloumbe (26) estimated that $<1 \%$ of $\mathrm{T}_{4}$ in fetal serum at term is derived from the maternal thyroid. Data in the $\mathrm{MH}$ groups in the present study also suggest that the amount of maternal $T_{4}$ that crosses the placenta under physiological conditions is negligible since 21-d fetal serum TSH concentrations were not affected by thyroidectomizing the dams early in pregnancy.

An important reason for developing these models was to determine whether alterations in $\mathrm{AF} \mathrm{rT}_{3}$ could predict fetal hypothyroidism in the rat and to determine the source of $\mathrm{rT}_{3}$ in the AF. The present data indicates that at term the majority of $\mathrm{AF} \mathrm{rT}_{3}$ is derived from maternal rather than fetal sources and does not provide evidence that $\mathrm{AF} \mathrm{rT}_{3}$ can be used to predict fetal thyroid function in the rat. In the presence 
of maternal hypothyroidism, AF $\mathrm{rT}_{3}$ concentrations were strikingly reduced irrespective of fetal thyroid function. Moreover, $\mathrm{AF} \mathrm{rT}_{3}$ was not decreased in the presence of fetal hypothyroidism alone, offering further evidence that the fetal thyroid contributes little to AF $\mathrm{rT}_{3}$. Because the extent of the decrease in serum $\mathrm{T}_{4}$ concentration in the hypothyroid fetus could not be determined, complete absence of $\mathrm{T}_{4}$ in the fetus might have resulted in a decrease in $\mathrm{AF} \mathrm{rT}_{3}$. Although absolute fetal thyroid agenesis in the rat may, therefore, be associated with reduced $\mathrm{AF} \mathrm{rT}_{3}$ concentrations, the above data suggests that this reduction would be small.

In contrast to the findings in amniotic fluid, fetal serum $\mathrm{rT}_{3}$ concentrations were, in general, reduced and to the same degree in the presence of either maternal or fetal hypothyroidism. When both maternal and fetal hypothyroidism were present, fetal serum $\mathrm{rT}_{3}$ concentrations were even lower or undetectable. These data suggest an approximately equal contribution to serum $\mathrm{rT}_{3}$ concentration by maternal and fetal sources of $\mathrm{T}_{4}$. It is unlikely, therefore, that $\mathrm{AF} \mathrm{rT}_{3}$ concentration is directly dependent upon fetal serum $\mathrm{rT}_{3}$.

In view of these complex findings, it is most difficult at the present time to define the mechanism(s) whereby maternal thyroid secretion of $T_{4}$ directly affects the concentration of $\mathrm{rT}_{3}$ in amniotic fluid. Direct transfer of $\mathrm{rT}_{3}$ from maternal serum or by way of the fetus to the AF is unlikely, in that the constant infusion of large quantities of $\mathrm{rT}_{3}$ to $\mathrm{MFH}$ rats resulted in a 35-fold increase in maternal serum $\mathrm{rT}_{3}$ concentration, a twofold increase in fetal serum $\mathrm{rT}_{3}$ concentration, and only a minimal effect on AF $\mathrm{rT}_{3}$. These findings also tend to rule out a contribution to AF of fetal serum $\mathrm{rT}_{3}$, which could conceivably arise from the placental conversion of maternal $T_{4}$ to $\mathrm{rT}_{3}$. Placental transfer of $\mathrm{T}_{4}$ from dam to fetus under physiologic conditions is minimal (26), therefore it is unlikely that sufficient maternal $\mathrm{T}_{4}$ would reach the fetus and be a major source of $\mathrm{AF} \mathrm{rT}_{3}$ generated in fetal liver or kidney. Two other possibilities remain. Direct transfer of $\mathrm{T}_{4}$ from the dam to the amniotic fluid and the conversion of this $\mathrm{T}_{4}$ or $\mathrm{rT}_{3}$ by amniotic fluid cells in the amniotic fluid, or the amniotic sac. In the sheep, evidence for in vivo and in vitro conversion of $\mathrm{T}_{4}$ to $\mathrm{rT}_{3}$ in amniotic fluid has been reported (27). This might be possible because, in the sheep, it has been suggested that a small quantity of $\mathrm{T}_{4}$ is directly transferred from mother to the amniotic fluid (28). The final, and most attractive hypothesis, is that maternal $\mathrm{T}_{4}$ is deiodinated to $\mathrm{rT}_{3}$ at a tissue site in the region of the maternal compartment and the amniotic sac with direct transfer of this $\mathrm{rT}_{3}$ into the amniotic fluid. A possible site for this conversion to $\mathrm{rT}_{3}$ and its subsequent transfer into the amniotic fluid is the chorion. This tissue, as demonstrated in a re- cent study by Murphy (29), is metabolically active, has different enzyme systems than the placental cotyledons, is frequently adherent to the maternal decidua, and is separated from the amniotic cavity only by the thin amnion which is permeable to other hormones such as the adrenal steroids. Very preliminary data do suggest that rat and human chorion convert $T_{4}$ to $\mathrm{rT}_{3}$ but not to $T_{3}$ as determined by incubation of chorion homogenates with ${ }^{125} \mathrm{I}-\mathrm{T}_{4}$ and analysis of the labeled products by descending paper chromatography in hexane-tertiary amyl alcohol-2N $\mathrm{NH}_{3}(1: 5: 6, \mathrm{vol} / \mathrm{vol} / \mathrm{vol})$.

In summary, the present studies demonstrate that models of maternal-fetal hypothyroidism, maternal hypothyroidism, and fetal hypothyroidism, that approximate the ideal have been developed in the rat. $\mathrm{rT}_{3}$ is present in fetal rat serum and AF. The concentration is approximately fivefold lower in fetal rat serum at term than that reported in human cord blood (30) and about threefold lower in rat AF than that reported in the human at term (2-6). We are unaware of any other reports demonstrating $\mathrm{rT}_{3}$ in rat amniotic fluid. It seems evident that, in the rat, $\mathrm{AF} \mathrm{rT}_{3}$ derives primarily from maternal sources of $T_{4}$. In view of these results in the rat and the recent report that $\mathrm{AF} \mathrm{rT}_{3}$ values were not useful in predicting fetal hypothyroidism in two patients (31), the possibility must be considered that, in man, $\mathrm{AF} \mathrm{rT}_{3}$ does not reflect fetal thyroid status.

\section{ACKNOWLEDGMENTS}

We thank Linda A. Carreaux and Anne Dodwell for expert secretarial assistance and Dr. Leslie Lipworth for assistance in the statistical evaluation of the data.

This work was supported by Research Grant AM-08919 from the National Institute of Arthritis, Metabolism, and Digestive Diseases, National Institutes of Health, Bethesda, Md.

\section{REFERENCES}

1. Kenny, F. M., A. H. Klein, A. V. Augustin, and T. P. Foley, Jr. 1975. Sporadic cretinism. In Perinatal Thyroid Physiology and Disease. D. A. Fisher and G. N. Burrow, editors, Raven Press, New York. 133-143.

2. Chopra, I. J., and B. F. Crandell. 1975. Thyroid hormones and thyrotropin in amniotic fluid. N. Engl. J. Med. 293: 740-743.

3. Burman, K. D., J. Read, R. C. Dimond, D. Strum, F. D. Wright, W. Patow, J. M. Earll, and L. Wartofsky. 1976. Measurements of 3,3',5'-triiodothyronine (reverse $T_{3}$ ), 3,3'-L-diiodothyronine, $T_{3}$, and $T_{4}$ in human amniotic fluid and in cord and maternal serum. J. Clin. Endocrinol. Metab. 43: 1351-1359.

4. Cooper, E., D. M. Manning, A. H. MacLennan, and C. W. Burke. 1977. Thyroid hormones in human amniotic fluid: detection of triiodothyronine and free levels of thyroxine, triiodothyronine and 3,3',5'-triiodothyronine. J. Endocrinol. 73: 44P.

5. Roti, E., F. Malavasi, P. Bandini, G. Robuschi, L. Benassi, and A. Gnudi. 1979. 3,3',5'-triiodothyronine concentrations in amniotic fluid at different stages of pregnancy. J. Endocrinol. Invest. 2: 213-216. 
6. Klein, A. H., B. E. P. Murphy, R. Artal, T. H. Oddie, and D. A. Fisher. 1980. Amniotic fluid thyroid hormone concentrations during human gestation. Am. J. Obstet. Gynecol. 136: 626-630.

7. Fisher, D. A. 1975. Reverse triiodothyronine and fetal thyroid status. N. Engl. J. Med. 293: 770-771.

8. Chopra, I. J., D. R. Hollingsworth, S. L. Davis, R. P. Belin, and M. C. Reid. 1979. Amniotic fluid 3,3'- and 3,5'-diiodothyronine in fetal hypothyroidism in sheep. Endocrinology. 104: 596-598.

9. Eayrs, J. T. 1955. The cerebral cortex of normal and hypothyroid rats. Acta Anat. 25: 160-183.

10. Geel, S. E., and P. S. Timiras. 1967. The influence of neonatal hypothyroidism and of thyroxine on the ribonucleic acid and deoxyribonucleic acid concentrations of rat cerebral cortex. Brain Res. 4: 135-142.

11. Balazs, R., S. Kovacs, P. Teichgraber, W. A. Cocks, and J. T. Eayrs. 1968. Biochemical effects of thyroid deficiency on the developing brain. J. Neurochem. 15: 1335-1349.

12. Cocks, J. A., R. Balazs, A. L. Johnson, and J. T. Eayrs. 1970. Effect of thyroid hormone on the biochemical maturation of rat brain: conversion of glucose-carbon into amino acids. J. Neurochem. 17: 1275-1285.

13. Craff, B. G. 1970. Synapses and membranous bodies in experimental hypothyroidism. Brain Res. 18: 297-307.

14. Nicholson, J. L., and J. Altman. 1972. The effects of early hypo- and hyperthyroidism on the development of rat cerebellar cortex. I. Cell proliferation and differentiation. Brain Res. 44: 13-23.

15. Rosman, N. P., M. J. Malone, M. Helfenstein, and E. Kraft. 1972. The effect of thyroid deficiency on myelination of brain. Neurology. 22: 99-105.

16. Gourdon, J., J. Clos, C. Coste, J. Dainat, and J. Legrand. 1973. Comparative effects of hypothyroidism, hyperthyroidism and undernutrition on the protein and nucleic acid contents of the cerebellum in the young rat. $J$. Neurochem. 21: 861-871.

17. Dussault, J. H., and P. Walker. 1978. The effect of iodine deficiency and propylthiouracil on the hypothalamopituitary-thyroid axis in the neonatal rat. Can. J. Physiol. Pharmacol. 56: 950-955.

18. Pickering, D. E., and D. A. Fisher. 1953. Growth and metabolism in normal and thyroid-ablated infant rhesus monkeys (Macaca Mulatta). Am. J. Dis. Child. 86: 11-22.
19. Holt, A. B., D. B. Cheek, and G. R. Kerr. 1973. Prenatal hypothyroidism and brain composition in a primate. Nature (Lond.). 243: 413-415.

20. Hamburgh, M., E. Lynn, and E. P. Weiss. 1964. Analysis of the influence of thyroid hormone on prenatal and postnatal maturation of the rat. Anat. Rec. 150: 147-162.

21. Eisenstein, Z., S. Hagg, A. G. Vagenakis, S. L. Fang, B. Ransil, A. Burger, A. Balsam, L. E. Braverman, and S. H. Ingbar. 1978. Effect of starvation of the production and peripheral metabolism of $3,3^{\prime}, 5^{\prime}$-triiodothyronine in euthyroid obese subjects. J. Clin. Endocrinol. Metab. 47: 889-893.

22. Amitage, P. 1971. Statistical Methods in Medical Research. John Wiley \& Sons, Inc., New York. 398-399.

23. Gray, B., and V. A. Galton. 1974. The transplacental passage of thyroxine and fetal thyroid function in the rat. Acta Endocrinol. 75: 725-733.

24. Connors, J. M., and G. A. Hedge. 1980. Feedback effectiveness of periodic versus constant triiodothyronine replacement. Endocrinology. 106: 911-917.

25. Tonooka, N., and M. A. Greer. 1980. The effect of graded doses of thyroxine on plasma thyrotropin concentration in rats made hypothyroid by thyroidectomy or propylthiouracil. Endocrinology. 106: 818-822.

26. Dussault, J.H., and P. Coulombe. 1980. Minimal placental transfer of L-thyroxine $\left(\mathrm{T}_{4}\right)$ in the rat. Pediatr. Res. 14: 288-231.

27. Riddick, D. H., I. A. Maslar, A. A. Luciano, and J. R. Raye. 1979. Thyroxine uptake and metabolism by fetal sheep after intra-amniotic thyroxine injection. Am. J. Obstet. Gynecol. 133: 618-623.

28. Sack, J., and D. A. Fisher. 1975. Thyroid hormone metabolism in amniotic fluid of man and sheep. In Perinatal Thyroid Physiology and Disease. D. A. Fisher and G.N. Burrow, editors. Raven Press, New York. 49-58.

29. Murphy, B. E. P. 1977. Chorionic membrane as an extra adrenal source of foetal cortisol in human amniotic fluid. Nature (Lond.). 266: 179-181.

30. Chopra, I. J., J. Sack, and D. A. Fisher. 1975. Circulating $3,3^{\prime}, 5^{\prime}$-triiodothyronine (reverse $\mathrm{T}_{3}$ ) in the human newborn. J. Clin. Invest. 55: 1137-1141.

31. Landau, H., J. Sack, H. Frucht, Z. Palti, D. HochnerCelnikier, and A. Rosenmann. 1980. Amniotic fluid $3,3^{\prime}, 5^{\prime}$-triiodothyronine in the detection of congenital hypothyroidism.J. Clin. Endocrinol. Metab. 50: 799-801. 